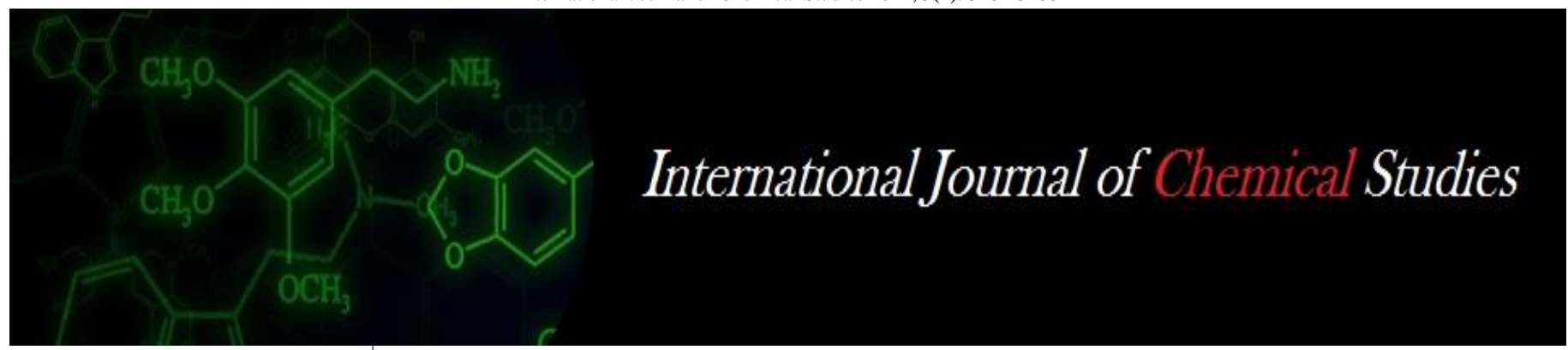

P-ISSN: 2349-8528

E-ISSN: 2321-4902

www.chemijournal.com

IJCS 2021; 9(1): 3284-3288

(C) 2021 IJCS

Received: 13-11-2020

Accepted: 24-12-2020

\section{GR Pardhi}

Post Graduate Student,

Department of Soil Science and

Agriculture Chemistry, PGI,

Mahatma Phule Krishi

Vidyapeeth, Rahuri,

Maharashtra, India

\section{Dr. PU Bhosale}

Assistant Professor, N.A.R.P., Ganeshkhind Pune, Mahatma

Phule Krishi Vidyapeeth,

Rahuri, Maharashtra, India

Dr. AD Kadlag

Ex Soil Chemist (STCR),

Department of Soil Science and

Agriculture Chemistry, Mahatma

Phule Krishi Vidyapeeth,

Rahuri, Maharashtra, India

\section{Dr. SD Kale}

Assistant Professor, Department of Soil Science and Agriculture

Chemistry, Mahatma Phule

Krishi Vidyapeeth, Rahuri,

Maharashtra, India

\section{Effect of organic manure incubated biochar on soil carbon pools during maize grown on Inceptisol}

\author{
GR Pardhi, Dr. PU Bhosale, Dr. AD Kadlag and Dr. SD Kale
}

DOI: https://doi.org/10.22271/chemi.2021.v9.i1at.11742

\begin{abstract}
A field experiment was conducted at Instructional Farm, Department of soil science and agriculture chemistry, Post Graduate Institute, MPKV, Rahuri during kharif season of 2019-20 to find out effect of organic manure incubated biochar on soil carbon pools at harvest of maize grown on Inceptisol. The field experiment consist of nine treatments viz., Absolute control, GRDF (120:60:40 kg ha ${ }^{-1} \mathrm{~N}_{1} \mathrm{P}_{2} \mathrm{O}_{5}$ and $\mathrm{K}_{2} \mathrm{O}$ $+10 \mathrm{t} \mathrm{ha}^{-1}$ Farm yard manure), GRDF (120:60:40 kg ha-1 $\mathrm{N}, \mathrm{P}_{2} \mathrm{O}_{5}$ and $\mathrm{K}_{2} \mathrm{O}+5 \mathrm{t} \mathrm{ha}^{-1}$ poultry litter), Biochar incubated with FYM in 1:1, 1:2 and 1:3 proportion and biochar incubated with poultry litter in 1:1, 1:2 and 1:3 proportion. These treatments replicated thrice in randomized block design. The soil organic carbon fractions were significantly influenced by the biochar incubated with the FYM and poultry litter. The soil organic carbon significantly beneficial at tasseling stage in biochar incubated with FYM in 1:1 proportions (1.06\%) and at harvest in 1:3 proportion $(0.94 \%)$. The biochar incubated with FYM in 1:2 proportion recorded the significantly highest total organic carbon at tasseling $(1.59 \%)$ and harvest in 1:3 proportion (1.40\%). The soil microbial biomass carbon was significantly more in GRDF with $10 \mathrm{t} \mathrm{ha}^{-1} \mathrm{FYM}$ at tasseling and harvest (238.79\% and $\left.114.52 \%\right)$. The water soluble carbon content at tasseling stage of maize was significant in biochar incubated with FYM in $1: 3$ proportions $\left(38.0 \mathrm{~g} \mathrm{~kg}^{-1}\right)$ and at harvest in biochar incubated with poultry litter in $1: 3$ proportions $\left(34.0 \mathrm{~g} \mathrm{~kg}^{-1}\right)$. The treatment biochar incubated with FYM in 1:2 proportions was significant at tasseling and harvest for particulate organic carbon (1.58 and $\left.1.47 \mathrm{~g} \mathrm{~kg}^{-1}\right)$ and potassium permanganate oxidizable organic carbon (1.86 and $\left.1.86 \mathrm{~g} \mathrm{~kg}^{-1}\right)$.
\end{abstract}

Keywords: Biochar, soil carbon pools, POXc, Pomc, SMBC, WSC

\section{Introduction}

In intensive agriculture, there is increasing demand of organic inputs with the objectives of increasing soil health and crop yields under climate change scenario. Conventionally, we have been using organic manure like farm yard manure (FYM), compost, vermicompost, green manure and crop residues for increasing carbon content and maintaining soil health. Unfortunately due to microbial attack and oxidation, stability of organic matter is decreasing day by day. Rather carbon sequestration for long time organic matter added to soil finds its way to atmosphere after decay and it lost as green house gases, such as carbon dioxide and methane. Despite of huge application of organic matter, the net change in soil carbon content is not increased significantly. For long duration carbon sequestration in soil, carbonaceous material like charcoal and biochar may be better option as its durability is long-lasting. As an evidence, historical use of biochar dates back at least 2000 years. In the Amazon Basin, extensive use of biochar can be found in the unusually fertile soil known as Terra Preta and Terra Mulata (O’Neill et al. 2009) ${ }^{[9]}$. Studies on Amazon soils have revealed that charcoal was used from ancient civilizations as soil amendment for agriculture purpose (Marris, 2006) [16]. Although several centuries have past, charcoal is still used in those areas for maintaining green and flourishing field. Due to such significant impact, biochar has become of great scientific interest and soil amendment with biochar is evaluated as means to improve soil fertility and crop yields.

Biochar is a fine-grained, highly porous charcoal substance that is distinguished from other charcoals in its intended use as a soil amendment in agriculture.
Corresponding Author: GR Pardhi

Post Graduate Student, Department of Soil Science and Agriculture Chemistry, PGI, Mahatma Phule Krishi Vidyapeeth, Rahuri, Maharashtra, India 
The carbon-rich residual solid by-product of thermo-chemical degradation of crop and agroforestry residues in an oxygen depleted environment (pyrolysis) is termed 'biochar' (Lehmann et al. 2011) ${ }^{[6]}$. Therefore biochar is capable to increase the rate of soil carbon sequestration through shift from short term bio atmospheric carbon cycle to the long term geological carbon cycle and improve fertility and crop yield. In India, biochar from residues of maize, castor, cotton and pigeonpea can sequester about $4.6 \mathrm{Mt}$. of total carbon annually in soil, making it a carbon sequestering process (Venkatesh et al. 2015) ${ }^{[13]}$. All these benefits to provide the basis for up scaling of biochar use in agriculture.

Maize is called queen of cereals as is grown throughout the year due to its photo thermo sensitive character and highest genetic yield potential among the cereals. Maize belongs to the tribe Maydeae of the grass family poaceae. Zea was derived from an old greek name for a food grass. The Zea mays L. is economically important. The centre of origin for Zea mays has been established as the Mesoamerican region, now mexico and central America. The number of chromosomes in Zea mays is $2 \mathrm{n}=20$ (Murdia et al. 2016) ${ }^{[8]}$. It is nutritionally superior to most other cereals as it contains $9.0 \%$ protein, $3.4 \%$ fat, $1.1 \%$ ash, $1.0 \%$ fibre, $0.30 \%$ thiamine, $0.08 \%$ riboflavin and $1.9 \%$ niacin (Paliwal, 2000) [10] In India maize is grown throughout the year. It is predominantly a kharif crop with 85 per cent of the area under cultivation in this season. Maize is the third most important cereal crop in India after rice and wheat. It accounts around 10 per cent of total food grain production in the country. Total production of maize including kharif and rabi season was 28752 thousand tonne in 9380 thousand hectare during 201718. Average productivity of maize in India was $3065 \mathrm{~kg} \mathrm{ha}^{-1}$ during 2017-18 (Anonymous, 2019) ${ }^{[1]}$. In this context, the present investigation was conducted in order to know the "Effect of organic manure incubated biochar on soil carbon during maize grown on Inceptisols."

\section{Material and Methods}

A field experiment was conducted at Instructional Farm, Department of soil science and agriculture chemistry, Post Graduate Institute, MPKV, Rahuri during kharif season of 2019-20.Geographically the location of experimental site was $19^{0} .34^{\prime} \mathrm{N}$ latitude and $74^{0} .64^{\prime}$ E longitude The experimental soils was medium deep black, belonging to Inceptisol order and taxonomically classified as fine Montmorillonitic isohyperthermic family of Vertic Haplustept. The soils of experimental plot are dominant with smectite type of clay mineral having high swell-shrink property. Biochar was prepared at PGI Research Farm, Department of Soil Science and Agriculture Chemistry by pyrolysis Klin method with help of metallic drum and brick. Cotton stalk was filled in the metallic drum then it closed with lid and kept inside brick walled kiln and converted into biochar through pyrolysis. Biochar was mixed with FYM and poultry litter separately as per ratio given in treatment detailed for incubation for one month. The experiment was laid out in a randomized block design with 9 treatments and 3 replications. The gross plot size was $4.5 \mathrm{~m} \mathrm{x} 3.00 \mathrm{~m}$ i.e. $13.5 \mathrm{~m}^{2}$ and net plot size was $3.00 \mathrm{~m} \times 2.60 \mathrm{~m}$ i.e. $7.8 \mathrm{~m}^{2}$. The recommended spacing of 75 $\mathrm{x} 20 \mathrm{~cm}$ was adopted for dibbling of maize. The general recommended dose of nutrients (120:60:40 kg ha-1 $\mathrm{N}, \mathrm{P}_{2} \mathrm{O}_{5}$ and $\mathrm{K}_{2} \mathrm{O}$, respectively) were given to maize as per treatment details except $\mathrm{T}_{1}$ at the time of dibbling of maize. Treatment consists of $T_{1}$ : Absolute control, $\mathrm{T}_{2}$ : GRDF (120:60:40 kg ha-1 + $10 \mathrm{t} \mathrm{ha}^{-1}$ FYM), T : GRDF (120:60:40 kg ha-1+5 $\mathrm{t} \mathrm{ha}^{-1}$ poultry litter), $\mathrm{T}_{4}$ : Biochar incubated with FYM (1:1) $(5+5=10$ $\left.\mathrm{t} \mathrm{ha}^{-1}\right), \mathrm{T}_{5}$ : Biochar incubated with FYM (1:2) $(3.34+6.66=10 \mathrm{t}$ $\left.\mathrm{ha}^{-1}\right), \mathrm{T}_{6}$ : Biochar incubated with FYM (1:3) $(2.5+7.5=10 \mathrm{t} \mathrm{ha}$ $\left.{ }^{1}\right), \mathrm{T}_{7}$ : Biochar incubated with Poultry litter $(1: 1)(2.5+2.5=5 \mathrm{t}$ $\left.\mathrm{ha}^{-1}\right), \mathrm{T}_{8}$ : Biochar incubated with Poultry litter (1:2) $\left(1.66+3.34=5 \mathrm{t} \mathrm{ha}^{-1}\right), \mathrm{T}_{9}$ : Biochar incubated with Poultry litter $(1: 3)\left(1.25+3.75=5 \mathrm{tha}^{-1}\right)$.

\section{Result and Discussion}

The data pertaining to effect of biochar application on maize are presented in table 1 and table 2. The organic carbon fractions at tasseling and harvest of maize was viz., soil organic carbon, total organic carbon, soil microbial biomass carbon, water soluble carbon, particulate organic matter (POMC) and particulate organic carbon (POXC) were significantly influenced by biochar incubated with FYM and poultry litter in the proportion of 1:1, 1:2 and 1:3, GRDF and absolute control.

\section{Soil organic carbon}

The soil organic carbon content at tasselling stage of maize was significantly higher in treatment $\left(\mathrm{T}_{5}\right)$ biochar incubated with FYM in the proportion of 1:2 (1.06\%) over rest of the treatments. The $\mathrm{T}_{6}$ treatment, biochar incubated with FYM in the proportion of $1: 3$ recorded $0.98 \%$ soil organic carbon and statistically on par with biochar incubated with FYM in the proportion of 1:1 (0.96\%). The soil organic carbon content of biochar $\left(\mathrm{T}_{9}\right)$ incubated with poultry litter was significantly higher $(0.81 \%)$ over biochar incubated with poultry litter in the $\mathrm{T}_{7}$ and $\mathrm{T}_{8}$ proportion of $1: 1$ and $1: 2(0.61$ and $0.67 \%)$. The latter two treatments were on par with each other for their soil organic carbon. The treatment GFDF $+10 \mathrm{tha}^{-1} \mathrm{FYM}$ recorded significantly higher soil organic carbon $(0.62 \%)$ than GRDF $+5 \mathrm{t} \mathrm{ha}^{-1}$ poultry litter and absolute control $(0.52$ and $0.50 \%$ ).

The soil organic carbon fraction was significantly higher in biochar incubated with FYM in the proportion of 1:3 at harvest stage of maize $(0.94 \%)$ and statistically on par with biochar incubated with FYM in the proportion of 1:1 $(0.90 \%)$. The biochar incubated with the FYM in the proportion of $1: 1$ and 1:2 was statistically on par with each other for soil organic carbon $(0.90$ and $0.85 \%)$. However, the organic carbon content in biochar incubated with FYM in the proportion of 1:1, 1:2 and 1:3 was significantly higher (0.90, 0.85 and $0.94 \%$ respectively) than the organic carbon content in biochar incubated with poultry litter in the proportion of $1: 1,1: 2$ and $1: 3(0.53,0.63$ and $0.66 \%$ respectively). The organic carbon content at tasseling stage in GRDF $+5 \mathrm{t} \mathrm{ha}^{-1}$ poultry litter, GRDF $+10 \mathrm{t} \mathrm{ha}^{-1} \mathrm{FYM}$ and absolute control recorded the least percentage and statistically on par with each other $(0.51,0.54$ and $0.49 \%$ respectively).

In general, soil organic carbon content at tasseling and at harvest stage of maize was significantly higher in biochar incubated with FYM than poultry litter. The carbon content in FYM might be easily oxidizable by soil microorganism and with held in porous structure of organic carbon. The organic carbon content in poultry litter depends on types of litter used in poultry yard, their composition, addition of poultry dropping including urine accelerates decomposition rate and release organic carbon in short span of time, which may subjected to oxidation process in soil in higher rate than their absorption in porous structure of biochar. In respect to proportion of biochar and poultry litter as 1:3 was suitable for increasing soil organic carbon in later growth stage of crop i.e. at harvest and early stage i.e. at taselling in 1:2 proportion 
was the best in respect to FYM and 1:3 for poultry litter. These observation are in accordance with the Yin et al. (2014) ${ }^{[15]}$ they found that treatment of soil + biochar showed the highest soil organic carbon, Satriawan and Handayanto (2015) [12] reported that the application of $40 \mathrm{t} \mathrm{ha}^{-1}$ maize biochar without litter and application of $40 \mathrm{t} \mathrm{ha}^{-1}$ litter with $40 \mathrm{t} \mathrm{ha}^{-1}$ maize biochar resulted in the highest soil organic carbon. Dume et al. (2016) ${ }^{[15]}$ reported that the application of biochar @ 0, 2.5, 5.0, 7.5, 10.0, 12.5 and $15.0 \mathrm{t} \mathrm{ha}^{-1}$ improved the organic carbon and organic matter of the soil.

\section{Total organic carbon}

The total organic carbon content at tasseling and harvest of maize was significantly influenced by the biochar incubated with FYM. It was significantly higher at taselling stage in $\left(\mathrm{T}_{5}\right)$ treatment, biochar incubated with FYM in the proportion 1:2 $(1.59 \%)$ and at harvest stage significantly higher observed in biochar incubated with FYM in the proportion 1:3 (1.40\%). It was on par with $\left(\mathrm{T}_{6}\right)$ biochar incubated with FYM in the proportion of 1:3 (1.47\%) at taselling and statistically on par with biochar incubated with FYM in the proportion of $1: 1$ $(1.34 \%)$ at harvest stage. The rest of the treatments were statistically on par with each other except absolute control. The lowest total carbon fraction was observed in absolute control at tasseling and harvest stage $(0.75 \%$ and $0.73 \%)$ followed by GRDF inclusion of poultry litter @ $5 \mathrm{t} \mathrm{ha}^{-1}$ $(0.78 \%$ and $0.76 \%)$ and biochar incubated with poultry litter in proportion of $1: 1(0.91 \%$ and $0.80 \%)$. The increased total carbon in soil might be because of biochar, FYM and poultry litter are the sources of carbon in soil. This is mainly because of substrate/ type of litter used for poultry yard, their C:N ratio, application period of litter in poultry yard in which poultry dropping was added. Similarly, in case of FYM, the $\mathrm{C}: \mathrm{N}$ ratio, content of FYM and their age. These results are in accordance with the results of Bera et al. (2016) ${ }^{[2]}$. They reported that mix biochar of oak and maple with RDF and dairy manure@22 t ha ${ }^{-1}$ in alkaline soil increase the total organic carbon of soil.

\section{Soil microbial biomass carbon}

The microbial biomass carbon content in soil at tasseling and harvest of maize was numerically higher in GRDF includes $10 \mathrm{t} \mathrm{ha}^{-1}$ FYM (238.79 and $114.52 \mathrm{mg} \mathrm{kg}^{-1}$ soil). However, at tasseling stage it was statically on par with biochar incubated with poultry litter $1: 1$ proportion $\left(227.42 \mathrm{mg} \mathrm{kg}^{-1}\right)$.It was followed by biochar incubation with FYM in 1:1 proportion and biochar incubated with poultry litter in 1:3 proportion at tasselling stage of maize (222.95 and $211.67 \mathrm{mg} \mathrm{kg}^{-1}$ soil). At harvest it was statistically on par with all treatments except absolute control and biochar incubated with poultry litter with $1: 1$ proportion (74.83 and $87.79 \mathrm{mg} \mathrm{kg}^{-1}$ soil). Bera et al. (2016) ${ }^{[2]}$ reported that mixed biochar of oak and maple with dairy manure @ $22 \mathrm{t} \mathrm{ha}^{-1}$ increased the soil microbial biomass carbon in soil. Bera et al. (2016) ${ }^{[2]}$ reported that the SMBC in alkaline soil increased by the addition of mixed biochar of oak and maple with RDF and diary manure @ $22 \mathrm{t} \mathrm{ha}^{-1}$. Gao et al. (2017) ${ }^{[5]}$ reported that application of rice husk biochar @ 4.5 $\mathrm{t} \mathrm{ha}^{-1}$ increases total organic carbon by $38.19 \%$.

\section{Water soluble carbon}

The water soluble carbon content in soil at tasseling stage of maize was significantly higher in biochar incubated with poultry litter in the proportion of $1: 3\left(38.0 \mathrm{mg} \mathrm{kg}^{-1}\right)$. It was statistically on par with biochar incubated with FYM in the proportion of $1: 1\left(35 \mathrm{mg} \mathrm{kg}^{-1}\right)$ and biochar incubated with poultry litter in $1: 1,1: 2$ and 1:3 proportion $(36,35$ and $34 \mathrm{mg}$ $\mathrm{kg}^{-1}$ respectively). The water soluble carbon was increased with increased proportion of biochar with FYM/ poultry litter at harvest stage. The water soluble carbon content at harvest of maize was significantly more in biochar incubated with poultry litter in the proportion of $1: 3\left(34.0 \mathrm{mg} \mathrm{kg}^{-1}\right.$ soil $)$ and statistically on par with biochar incubated with poultry litter in proportion 1:1 and 1:2 (33 and $32 \mathrm{mg} \mathrm{kg}^{-1}$ ). The biochar incubated with FYM in the proportion of 1:1, 1:2 and 1:3 were statistically on par with each other for water soluble carbon $\left(21.0,25.0\right.$ and $23.0 \mathrm{mg} \mathrm{kg}^{-1}$ soil respectively) at harvest stage of maize. The water soluble carbon content was more at taselling over at harvest stage. The rate of decrease in water soluble carbon from tasseling to harvest was more in biochar incubated with FYM than incubated with poultry litter. Similarly, it was increased with the increased proportion of biochar incubated with FYM and poultry litter in the proportion of 1:1, 1:2 and 1:3 respectively. This might be because of the addition of either FYM or poultry litter for incubating the biochar subjected to add the more carbon into the soil and over a period there was transformation of organic carbon from one form to another form by decomposition, microbial transformation or enzymatic transformation. These observations are confirmation of observations recorded by Sandhu et al. (2017) ${ }^{[11]}$ that water soluble carbon increased with the application of biochar of corn stover @ $10 \mathrm{Mg} \mathrm{ha}^{-1}$. Xing et al. (2015) ${ }^{[14]}$ showed that application of coarse biochar of bamboo and rice at $50 \%$ of amendment increase the water soluble carbon in soil.

\section{Particulate organic matter carbon}

Particulate organic matter carbon content at tasseling and harvest stage of maize was significantly influenced by the biochar incubated with FYM and poultry litter in the proportion of 1:1, 1:2 and 1:3 as well as GRDF with $10 \mathrm{t} \mathrm{ha}^{-1}$ FYM and GRDF $+5 \mathrm{t} \mathrm{ha}^{-1}$ poultry litter. The particulate organic carbon content in soil was found significantly the highest in biochar incubated with FYM in 1:1 proportion (1.58 and $1.47 \mathrm{mg} \mathrm{kg}^{-1}$ soil) at tasselling and at harvest stage respectively. It was followed by biochar incubated with FYM in $1: 1$ proportion ( 1.35 and $1.33 \mathrm{mg} \mathrm{kg}^{-1}$ ) at tasselling and at harvest stage respectively. The particulate organic matter carbon was numerically higher in biochar incubated with FYM than biochar incubated with poultry manure. The increased proportion of biochar incubation with FYM and poultry litter increased the particulate organic matter carbon in soil except 1:3 proportion of biochar incubated with FYM. GRDF inclusive of $10 \mathrm{t} \mathrm{ha}^{-1}$ FYM and GRDF inclusive of $5 \mathrm{t}$ $\mathrm{ha}^{-1}$ poultry litter record the least amount of particulate organic matter carbon at tasseling $\left(1.07\right.$ and $\left.1.08 \mathrm{mg} \mathrm{kg}^{-1}\right)$ and at harvest of maize (1.02 and $\left.1.10 \mathrm{mg} \mathrm{kg}^{-1}\right)$.

\section{Potassium permanganate oxidizable organic carbon}

The application of biochar incubated with FYM and poultry litter in the proportion of $1: 1,1: 2$ and $1: 3$ and also GRDF inclusive of $10 \mathrm{t} \mathrm{ha}^{-1} \mathrm{FYM}$ and $5 \mathrm{t} \mathrm{ha}^{-1}$ poultry manure significantly influenced the potassium permanganate oxidizable organic carbon in soil at tasseling and harvest stage of maize. It was significantly the highest in biochar incubated with FYM in the 1:2 proportion at tasseling and harvest stage (1.86 and $1.86 \mathrm{mg} \mathrm{kg}^{-1}$ ) and statistically on par with biochar incubated with FYM in 1:1 proportion (1.83 and $1.83 \mathrm{mg} \mathrm{kg}^{-}$ $\left.{ }^{1}\right)$. The rest of treatments were statistically on par with each other for potassium permanganate oxidizable organic carbon at tasseling and harvest stage of maize. These results are 
corroborated with the results of Demisie et al. (2014) ${ }^{[4]}$, they observed that the degraded soils amended with oak and bamboo biochar in three different rates as of $0.5,1.0$ and
$2.0 \%$ recorded the highest potassium permanganate oxidizable organic carbon in soil.

Table 1: Effect of organic manure incubated biochar on SOC, TOC and SMBC during maize grown on Inceptisol

\begin{tabular}{|c|c|c|c|c|c|c|c|}
\hline \multirow[t]{2}{*}{ Tr. No. } & \multirow[t]{2}{*}{ Treatment } & \multicolumn{2}{|c|}{$\begin{array}{c}\text { Soil organic carbon } \\
(\%)\end{array}$} & \multicolumn{2}{|c|}{$\begin{array}{c}\text { Total organic } \\
\text { carbon }(\%)\end{array}$} & \multicolumn{2}{|c|}{$\begin{array}{c}\text { Soil microbial biomass } \\
\text { carbon }\left(\mathrm{mg} \mathrm{kg}^{-1}\right)\end{array}$} \\
\hline & & Tasseling & At harvest & Tasseling & At harvest & Tasseling & At harvest \\
\hline $\mathrm{T}_{1}$ & Absolute control & 0.50 & 0.49 & 0.75 & 0.73 & 137.48 & 74.83 \\
\hline $\mathrm{T}_{2}$ & GRDF (120:60:40 kg ha-1 $\left.+10 \mathrm{t} \mathrm{ha}^{-1} \mathrm{FYM}\right)$ & 0.62 & 0.54 & 0.92 & 0.80 & 238.79 & 114.52 \\
\hline $\mathrm{T}_{3}$ & GRDF (120:60:40 $\mathrm{kg} \mathrm{ha}^{-1}+5 \mathrm{t} \mathrm{ha}^{-1}$ poultry litter) & 0.52 & 0.51 & 0.78 & 0.76 & 177.34 & 107.19 \\
\hline $\mathrm{T}_{4}$ & Biochar incubated with FYM $(1: 1)\left(5+5=10 \mathrm{t} \mathrm{ha}^{-1}\right)$ & 0.96 & 0.90 & 1.44 & 1.34 & 222.95 & 94.92 \\
\hline $\mathrm{T}_{5}$ & Biochar incubated with FYM $(1: 2)\left(3.34+6.66=10 \mathrm{t} \mathrm{ha}^{-1}\right)$ & 1.06 & 0.85 & 1.59 & 1.27 & 141.29 & 105.93 \\
\hline $\mathrm{T}_{6}$ & Biochar incubated with FYM (1:3) $\left(2.5+7.5=10 \mathrm{t} \mathrm{ha}^{-1}\right)$ & 0.98 & 0.94 & 1.47 & 1.40 & 205.17 & 107.03 \\
\hline $\mathrm{T}_{7}$ & Biochar incubated with poultry litter $(1: 1)\left(2.5+2.5=5 \mathrm{t} \mathrm{ha}^{-1}\right)$ & 0.61 & 0.53 & 0.91 & 0.80 & 227.42 & 107.65 \\
\hline $\mathrm{T}_{8}$ & Biochar incubated with poultry litter $(1: 2)\left(1.66+3.34=5 \mathrm{t} \mathrm{ha}^{-1}\right)$ & 0.67 & 0.63 & 1.00 & 0.94 & 144.89 & 87.79 \\
\hline \multirow[t]{4}{*}{$\mathrm{T}_{9}$} & Biochar incubated with poultry litter $(1: 3)\left(1.25+3.75=5 \mathrm{t} \mathrm{ha}^{-1}\right)$ & 0.81 & 0.66 & 1.21 & 0.99 & 211.67 & 110.99 \\
\hline & S.E. + & 0.02 & 0.02 & 0.04 & 0.03 & 4.28 & 5.55 \\
\hline & C.D. at $5 \%$ & 0.06 & 0.06 & 0.12 & 0.09 & 12.84 & 16.65 \\
\hline & Initial & 0.46 & - & 0.69 & - & 73 & - \\
\hline
\end{tabular}

Table 2: Effect of organic manure incubated biochar on WSC, POMC and POXC during maize grown on Inceptisol

\begin{tabular}{|c|c|c|c|c|c|c|c|}
\hline \multirow[t]{2}{*}{$\begin{array}{l}\text { Tr. } \\
\text { No. }\end{array}$} & \multirow[t]{2}{*}{ Treatment } & \multicolumn{2}{|c|}{$\begin{array}{c}\text { Water soluble } \\
\text { carbon }\left(\mathrm{mg} \mathrm{kg}^{-1}\right)\end{array}$} & \multicolumn{2}{|c|}{$\begin{array}{c}\text { Particulate organic } \\
\text { matter carbon }\left(\mathrm{g} \mathrm{kg}^{-1}\right)\end{array}$} & \multicolumn{2}{|c|}{\begin{tabular}{|c|} 
Potassium permanganate \\
oxidizable organic \\
carbon $\left(\mathrm{mg} \mathrm{kg}^{-1}\right)$
\end{tabular}} \\
\hline & & Tasseling & At harvest & Tasseling & At harvest & Tasseling & At harvest \\
\hline $\mathrm{T}_{1}$ & Absolute control & 17.33 & 12.00 & 0.98 & 0.95 & 1.76 & 1.74 \\
\hline $\mathrm{T}_{2}$ & GRDF (120:60:40 kg ha-1 $\left.+10 \mathrm{t} \mathrm{ha}^{-1} \mathrm{FYM}\right)$ & 27.00 & 17.33 & 1.07 & 1.02 & 1.80 & 1.76 \\
\hline $\mathrm{T}_{3}$ & GRDF (120:60:40 kg ha ${ }^{-1}+5 \mathrm{t} \mathrm{ha}^{-1}$ poultry litter) & 22.00 & 16.33 & 1.08 & 1.10 & 1.77 & 1.77 \\
\hline $\mathrm{T}_{4}$ & Biochar incubated with FYM $(1: 1)\left(5+5=10 \mathrm{t} \mathrm{ha}^{-1}\right)$ & 35.00 & 21.00 & 1.35 & 1.33 & 1.83 & 1.83 \\
\hline $\mathrm{T}_{5}$ & Biochar incubated with FYM $(1: 2)\left(3.34+6.66=10 \mathrm{t} \mathrm{ha}^{-1}\right)$ & 30.00 & 25.00 & 1.58 & 1.47 & 1.86 & 1.86 \\
\hline $\mathrm{T}_{6}$ & Biochar incubated with FYM (1:3) $\left(2.5+7.5=10 \mathrm{t} \mathrm{ha}^{-1}\right)$ & 38.00 & 23.00 & 1.30 & 1.23 & 1.78 & 1.86 \\
\hline $\mathrm{T}_{7}$ & Biochar incubated with poultry litter $(1: 1)\left(2.5+2.5=5 \mathrm{t} \mathrm{ha}^{-1}\right)$ & 36.00 & 33.00 & 1.17 & 1.11 & 1.77 & 1.76 \\
\hline $\mathrm{T}_{8}$ & Biochar incubated with poultry litter $(1: 2)\left(1.66+3.34=5 \mathrm{t} \mathrm{ha}^{-1}\right)$ & 35.00 & 32.00 & 1.22 & 1.18 & 1.79 & 1.75 \\
\hline $\mathrm{T}_{9}$ & Biochar incubated with poultry litter $(1: 3)\left(1.25+3.75=5 \mathrm{t} \mathrm{ha}^{-1}\right)$ & 34.00 & 34.00 & 1.26 & 1.28 & 1.75 & 1.77 \\
\hline & S.E. + & 1.64 & 1.69 & 0.03 & 0.04 & 0.02 & 0.029 \\
\hline & C.D. at $5 \%$ & 4.92 & 5.05 & 0.09 & 0.13 & 0.06 & 0.088 \\
\hline & Initial & 9 & - & 0.89 & - & 1.37 & - \\
\hline
\end{tabular}

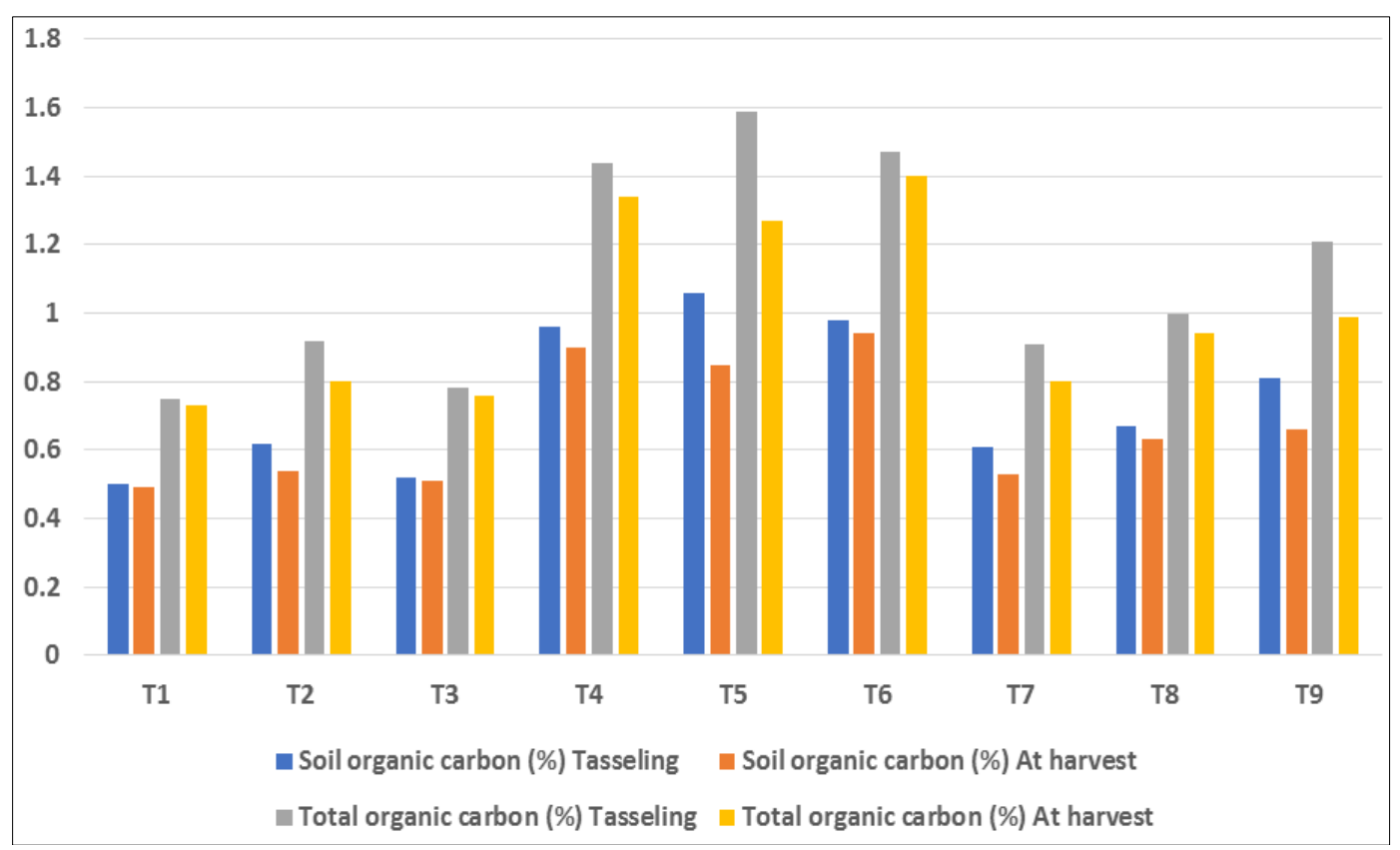

Fig 1: Effect of biochar incubated FYM and poultry litter on SOC and TOC during maize grown on inceptisol 


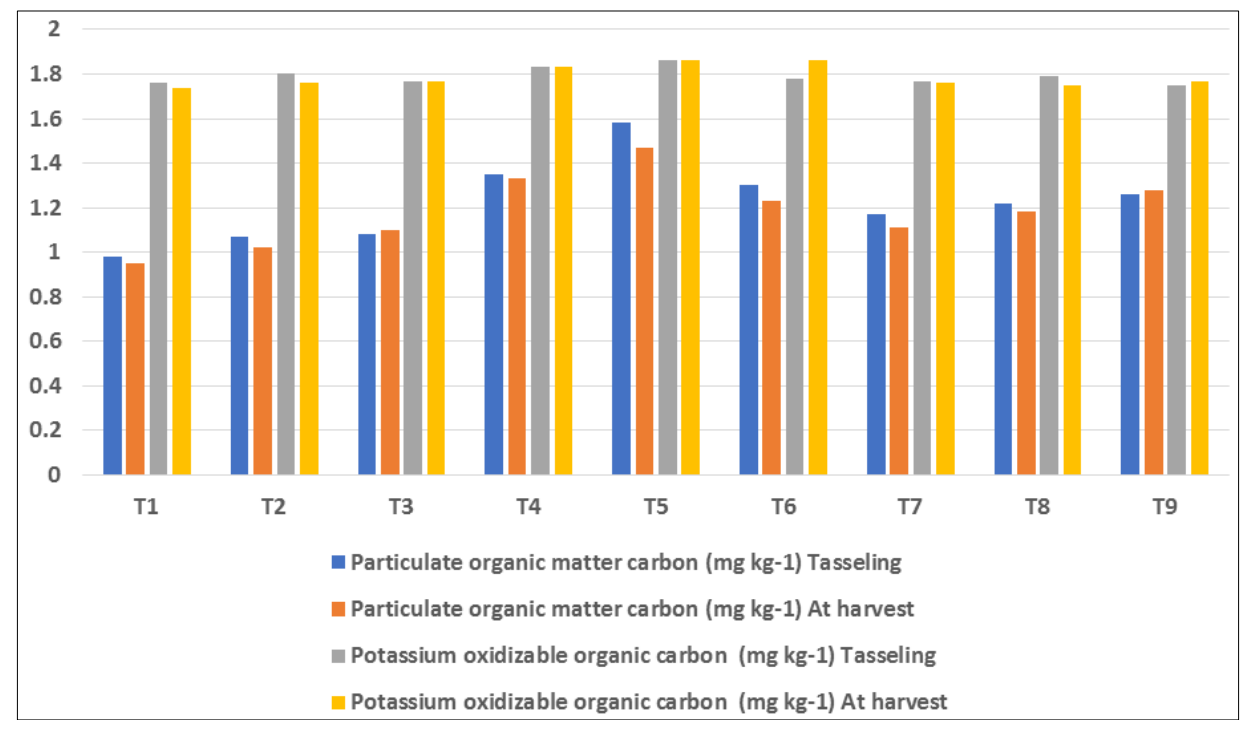

Fig 2: Effect of biochar incubated FYM and poultry litter on POMC and POXC during maize grown on inceptisol

\section{Conclusion}

The soil organic carbon fractions were significantly influenced by the biochar incubated with FYM and poultry litter in various proportions and GRDF with inclusion of $10 \mathrm{t}$ $\mathrm{ha}^{-1}$ FYM and $5 \mathrm{t} \mathrm{ha}^{-1}$ poultry litter. The soil organic carbon significantly higher at tasseling stage in biochar incubated with FYM in $1: 1$ proportions $(1.06 \%)$ and at harvest in $1: 3$ proportion (0.94\%). The biochar incubated with FYM in 1:2 proportion recorded significantly highest total organic carbon at tasseling $(1.59 \%)$ and harvest in $1: 3$ proportion $(1.40 \%)$. The soil microbial biomass carbon was significantly more in GRDF with $10 \mathrm{t} \mathrm{ha}^{-1}$ FYM at tasseling and harvest $(238.79 \%$ and $114.52 \%$ ).

The water soluble carbon content at tasseling stage of maize was significant in biochar incubated with FYM in 1:3 proportions $\left(38.0 \mathrm{~g} \mathrm{~kg}^{-1}\right)$ and at harvest in biochar incubated with poultry litter in 1:3 proportions $\left(34.0 \mathrm{~g} \mathrm{~kg}^{-1}\right)$. The treatment biochar incubated with FYM in 1:2 proportions was significant at tasseling and harvest for particulate organic carbon (1.58 and $1.47 \mathrm{~g} \mathrm{~kg}^{-1}$ ) and potassium permanganate oxidizable organic carbon (1.86 and $\left.1.86 \mathrm{~g} \mathrm{~kg}^{-1}\right)$.

\section{Reference}

1. Anonymous. Agricultural Statistics At A Glance. Ministry of Agriculture and Farmers Welfare; Directorate of Economics and Statistics, Govt. of India 2018-2019.

2. Bera T, Collinsa HP, Alvaa AK, Purakayasthad TJ, Patra AK. Biochar and manure effluent effects on soil biochemical properties under corn production. Applied Soil Ecology 2016;107:360-367.

3. Dume B, Ayele D, Regassa A, Barecha G. Interactive effects of biochar in soil related to feedstock and pyrolysis temperature. American Eurasian Journal of Agriculture Environment Science 2016;16(3):442-448.

4. Demisie W, Liua Z, Zhang M. Effect of biochar on carbon fractions and enzyme activity of red soil. Catena 2014;121:214-221.

5. Gao Lin, Wang Rui, Shen Guoming, Zhang Jixu, Meng Guixing, Zhang Jiguang. Effects of biochar on nutrients and the microbial community structure of tobaccoplanting soils. Journal of Soil Science and Plant Nutrition 2017;17(4):884-896.

6. Lehmann J, Rillig MC, Thies J, Masiello CA, Hockaday WC, Crowley D. Biochar effects on soil biota. Soil Biology and Biochemistry 2011;43:1812-1836.
7. Khandait VN, Tiple AV, Dhenge SA. Assessment of relationship between personal and socio-economic characteristics with adoption of backyard poultry rearing practices in Bhandara district of Maharashtra. Int. J Agric. Extension Social Dev. 2020;3(1):58-62.

8. Murdia LK, Wadhwani R, Wadhwan N, Bajpai P, Shekhawat S. Maize utilization in India. American Journal of Food and Nutrition 2016;4(6):169-176.

9. O’Neill B, Grossman J, Tsai MT, Gomes JE, Lehmann J, Peterson $\mathrm{J}$ et al. Bacterial community composition in Brazilian Anthrosols and adjacent soils characterized using culturing and molecular identification. Microbial Ecology 2009;58:23-35.

10. Paliwal RL. Introduction to maize and its importance in improvement and production food and agriculture organization of the United Nations, Rome, Italy 2000.

11. Sandhu SS, David AN, Kumar S, Chintal R, Papiernik SK, Malo DD et al. Analyzing the impacts of three types of biochar on soil carbon fractions and physiochemical properties in corn-soybean ratio. Chemosphere 2017; 184:473-481.

12. Satriawan BD, Handayanto E. Effects of biochar and crop residues application on chemical properties of a degraded soil of South Malang, and P uptake by maize. Journal of Degraded and Mining Lands Management 2015;2(2):271280 .

13. Venkatesh G, Srinivasa Rao CH, Gopinath KA, Sammi Reddy K. Low-cost portable kiln for biochar production from on-farm crop residue. Indian Farming 2015;64(12):912,18

14. Xing Y, Liu J, Kim M, Haung H, Lu K, Xi G et al. Effect of biochar on the extractability of heavy metals and enzyme activity in soil. Environment Science and Pollution Research 2015. DOI:10.1007/s11356-015-42330.

15. Yin $\mathrm{Y}, \mathrm{He} \mathrm{X}$, Gao R, Ma H, Yang Y. Effect of rice straw and its biochar addition on soil labile carbon and soil organic carbon. Journal of Integrative Agriculture 2014;13(3):491-498.

16. Marris E. Black is the new green. Nature 2006;442:624626. 